\section{'Industry should have final say in fate of research centres'}

\section{London}

THE British government's evident wish for businessmen to dictate the direction of publicly financed scientific research will extend to the proposed university research centres if the chief science adviser in the Cabinet Office, Mr John Fairclough, has his way. The establishment of interdisciplinary research centres was one of the central recommendations by the Advisory Board for the Research Councils (ABRC) in recent advice to the Secretary of State for Education and Science, Mr Kenneth Baker, on ways to make more efficient use of the science budget (see Nature 328, 280; 1987). Although the concept of the centres has broad approval within academic and government circles, sharp differences are emerging on the question of the centres' management and control.

Speaking at a conference of businessmen and academics last week, Fairclough made it clear that the influence of the private sector over the centres is likely to be considerable. Institutions wishing to

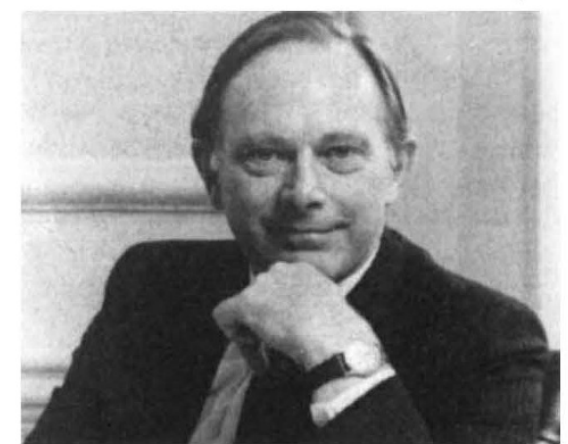

John Fairclough encourages business.

house a centre would bid for government funds with the principal criterion being "the strength and extent of the partnership with industry". Approximately 80 per cent of the research budget would go on 'strategic' science and 20 per cent on 'basic' science. There would be a 'sunset clause' agreed at the beginning of the centre's life which would require the centre's work to be reviewed after a specified period (probably between five and ten years), when a decision would be taken either to continue the work or to close the centre. "The principal judge in this review would be the industry partners." This view seems to be at odds with the perception of the ABRC, whose strategy advice says: "We believe the prime responsibility for considering the progress of research within the agreed framework of objectives should rest with the research managers closest to the work."

Fairclough was speaking at a conference entitled 'Wealth from Science', sponsored by the Patent Office and the research councils to discuss the commercial exploitation of academic research. The conference enabled the government matter, articulated on this occasion by the Education Secretary. The national scientific effort should derive from a "partnership" between industry and academic institutions, whose achievement will require a "cultural change" from both parties. ("In talking with young scientists I have met some who are working in areas of strategic research but who have never discussed it with an industrialist. Some have never even had a business lunch," an incredulous Baker told the audience.)

Not all industrialists favour the government's approach. Professor John Cadogan, of British Petroleum, holds that the function of a university is primarily to "produce excellent people at all levels and to reiterate its well-known thoughts on the
Tokyo

Mount Mihara, a volcano on Oshima island south of Tokyo, has blown its top again a year after a major eruption forced the temporary evacuation of the island (see Nature 324, 295; 1987). But, despite an array of sophisticated monitoring equipment, Japan's Volcanic Prediction Council is divided over the interpretation of the latest series of eruptions.

Oshima is the first in a chain of volcanic islands that stretches south for over 1,000 $\mathrm{km}$ along the edge of the Philippine plate. In mid-November last year, the volcano burst into a series of violent eruptions that led to the evacuation of the 10,000 inhabitants of the island.

At the time, the prediction council came under fire for its failure to forecast activity of the volcano. And in December last year, more than $¥ 1,000$ million ( $\$ 8$ million) was spent on new seismic equipment. The island now bristles with dozens of state-of-the-art seismometers and tiltmeters, earning it the nickname 'hedgehog'. But the volcano's behaviour is still proving difficult to predict. First signs of activity came 2 weeks ago as minor earthquakes shook the island, and the Meteorological Agency warned residents to watch for future reports. On Monday of last week, hours before the prediction council was due to hold a meeting to discuss the latest seismic activity, the volcano burst into life, spewing plumes of ash thousands of metres into the air.

At a hurriedly convened press conference, two members of the council said it

produce the knowledge base on which industry can build", not to become "nothing more than a contract organization".

But Mr Anthony Gray, of a technology transfer company, Cogent Ltd, would like to see academic institutions adopt an "entrepreneurial and pro-active approach if the full benefits of the wealth creation process of technology transfer are to be grasped".

The conference also focused on the question of ownership of intellectual property rights. Whereas industrial liaison directors in the universities favour the retention of the rights by the institution, with the granting of non-exclusive licences to commercial exploiters, many industries, unsurprisingly, prefer to obtain the rights, with an agreement to return them to the institution if after a specified time the rights had not been exploited. The Patent Office is presently running a 'general awareness' campaign aimed at academics, and the Department of Education is to review the field next year.

Simon Hadlington

\title{
Confusion over forecasts of Japanese volcanic eruption
}

was difficult to determine whether the eruption was the beginning of a series or a single isolated phenomenon. But Professor Yoshiaki Ida, head of the IzuOshima division of the council, said he thought that eruptions would continue. The next day, when the volcano had calmed down, an agency official explained that the eruption had been caused by a buildup of gas under the rocks piled up in the crater, and that, although similar eruptions might occur, the chance of a large eruption was very small.

Early on Wednesday morning the volcano burst into another series of four violent eruptions, the crater collapsed about $100 \mathrm{~m}$, and clouds of ash were again thrown thousands of metres into the air. In a 5-hour marathon session the same day, the council agreed that Wednesday's eruptions had been brought about by an increase in pressure at depth due to magma movements which caused the northwest side of the volcano to rise and the shore of the island to sink immediately before and during the eruptions. But the council is divided as to why the pressure at depth rose; some council members think lava from the old crater sank back into the magma chamber, while others say new magma came up from depth. At present, the council does not expect a major eruption with lava overflow, as happened last year, but in the long term such a possibility cannot be ruled out.

The islanders are taking no chances. On Saturday they held a practice drill for evacuation of the island. David Swinbanks 